\title{
Irodalommal nevelni
}

\section{Előszó a gyermekirodalmi számhoz}

\author{
Lózsi Tamás és Gönczöl Andrea \\ ELTE Tanitó- és Óvóképzö Kar Magyar Nyelvi és Irodalmi Tanszék
}

Az ELTE Tanító- és Óvóképző Kar által megjelentetett Gyermeknevelés Tudományos Folyóirat jelen számának fókuszában a gyermekirodalom és kutatásának szerteágazó kapcsolatrendszere áll. A színes, több perspektívát érintő, tudományterületeken átívelő tematikus szám írásainak közös jellemzője a gyermekirodalom interdiszciplinaritásának bemutatása és közvetítése. A gyermek- és ifúsági irodalom kutatási területei számos tudományághoz kapcsolódnak: átívelnek a határokon túl más népek kultúrtörténetébe, felvetnek nyelvészeti, folklórtörténeti, módszertani, tantárgy-pedagógiai témákat, kérdéseket.

A kötet számos írása az elméleti kutatások elemző bemutatása mellett az óvodai-iskolai oktató-nevelő munkában hasznosítható módszeres eljárások ismertetésére is vállalkozik, segítséget és ötleteket nyújtva ezáltal a pedagógusoknak a tanórai foglalkozások, óvodai tevékenységek élménypedagógiai, drámapedagógiai módszerekkel történő megvalósításához. A tanulmányok között megtalálhatjuk a folklórhoz kapcsolódó népmesekutatásokat, népmeseelemzéseket tartalmazó írásokat, így ismereteket szerezhetünk a Baranya megyei német népmesék nemzetiségi oktatásban betöltött szerepéről az Ördögcsúcs (Teufelsgipfel) című mesekötet bemutatásán keresztül (Márkus, 2021), izgalmas tanulmányt olvashatunk a kárpátaljai népmeséket tartalmazó Három arany nyílvessző címü gyűjtemény tulajdonneveinek rendszerezésével kapcsolatos kutatásról (Nagy, 2021).

A kötetben helyet kaptak a kortárs gyermek- és ifjúsági irodalomhoz köthető művek poétikai, retorikai, mondatgrammatikai szempontú bemutatását tárgyaló írások, így érdekes tanulmányt olvashatunk Berg Judit három „hisztimeséjének" retorikai elemzéséről, a meggyőzés és érvelés lélektanáról, technikáiról (Lózsi, 2021); Neil Gaiman Coraline címủ regényének komparatisztikai vizsgálatáról (Mukics, 2021); Keresztesi József Csücsök, avagy a nagy pudinghajsza című verses meseregényének narrato-poétikai jellegzetességeiről (Baka L., 2021); Borbáth Péter Együtt a Pörkeföldre címü mese- 
regényének szintaktikai jellemzőinek mondatgrammatikai vizsgálatáról (Gaál-Horváth, 2021), valamint Josef Michaelis Zauberhut címü, gyerekeknek szóló könyvének német nyelven írt ismertetéséről (Kerekes, 2021).

Színvonalas írásokat találhatunk a lapszámban az anyanyelvi hallgatólagos tudás és a gyermekirodalom kapcsolatáról, a gyermekirodalom anyanyelvi nevelésben, a nyelvi tudatosság kialakításában játszott szerepéről az úgynevezett RWCT-technika RJR-modelljének alkalmazásának ismertetésén keresztül (Pölcz, 2021) vagy a gyermekfolklór és a velünkszületettség elméletének közös vizsgálatáról (Balázs, 2021).

A tematikus szám műhelymunkái között hangsúlyos helyett kapott az olvasóvá nevelést célzó módszerek, technikák bemutatása. Izgalmas írást olvashatunk Kolozsi Angéla Bódog és Szomorilla címü kortárs magyar meseregénye drámapedagógiai eszközökkel történő feldolgozásának lehetőségeiről, kiváló ötleteket szolgáltatva az alsó tagozatos órai munkához (Gajdóné Gődény et al., 2021), egy másik írás által pedig megismerkedhetünk az óvodáskorú gyermekek irodalom iránti kíváncsiságának felébresztését motiváló, szövegértését, elaborációs képességét fejlesztő drámapedagógiai módszerekkel (Gönczöl, 2021).

A tematikus számban a gyermekek és tanítójuk által közösen készített verseskönyv szemléltetésén keresztül teret kapott a kreatív írás metodikájának méltatását tárgyaló tanulmány is , amely bebizonyítja, hogy a kreatív írásgyakorlatok hatékonyan alkalmazhatók az alsó tagozatos gyerekek képesség- és személyiségfejlesztésében (Grandpierre, 2021). Az aktuális társadalmi helyzetre reagáló írást olvashatunk egy online élőszavas mesemondó kurzus megvalósításának lépéseiről, a digitális eszközök kiaknázásának fortélyairól (Bumberák, 2021), valamint az iskolai gyakorlatba szintén rendkívül eredményesen beépíthető korszerü módszertani elem, a $\mathrm{LEGO}^{\circ}$ eszközzel történő digitális történetmesélésnek a gyermekirodalom oktatásában, interpretációjában betöltött szerepéről (Lengyelné Molnár et al., 2021).

Összegzésképpen elmondhatjuk, hogy a magyar és idegen nyelvü írásokban felvonultatott népmesék, mümesék, kortárs gyermekirodalmi müvek tolmácsolásával felszínre kerülnek a mai nyelvhasználat, az irodalmi művek anyanyelvi nevelésben betöltött helyének és szerepének kérdései, a szerzők írásaiban ötleteket és válogatási szempontokat kapunk az igényes, értékes gyermekirodalmi művek tudatos kiválasztásához, a gyermekek literációs szokásainak, nyelvi attitűdjük, érzelmi intelligenciájuk formálásához, valamint drámapedagógiai, módszertani, szakmai ötleteket az irodalmi mủvek gyerekekkel történő feldolgozásához. Jó olvasást, szakmai feltöltődést kívánunk!

\section{Irodalom}

Baka L., P. (2021). Keresztesi József: Csücsök, avagy a nagy pudinghajsza (Rajzolta: Horváth Ildi). Gyermeknevelés Tudományos Folyóirat, (9)1, 201-2017. https:// doi.org/10.31074/gyntf.2021.1.201.217 
Balázs, G. (2021). Mi születik velünk? Velünkszületettség: nyelv, gyermekfolklór. Gyermeknevelés Tudományos Folyóirat, (9)1, 87-98. https://doi.org/10.31074/ gyntf.2021.1.87.98

Bumberák, M. (2021). A Zoomperenciás-tengeren is túl - Egy online élőszavas mesemondó kurzus margójára. Gyermeknevelés Tudományos Folyóirat, (9)1, 320-326. https://doi.org/10.31074/gyntf.2021.1.320.326

Gaál-Horváth, K. (2021). Borbáth Péter Együtt a Pörkeföldre címủ meseregényének szintaktikai jellegzetességei. Gyermeknevelés Tudományos Folyóirat, (9)1, 230239. https://doi.org/10.31074/gyntf.2021.1.230.239

Gajdóné Gődény, A., Koósné Sinkó, J. \& Merényi, H. (2021). A regényolvasás (be) vezetése - meseregények az olvasóvá válás folyamatában. Gyermeknevelés Tudományos Folyóirat, (9)1, 261-299. https://doi.org/10.31074/ gyntf.2021.1.261.299

Grandpierre, A. (2021). Könyv születik. Kreatív írás alsó tagozaton. Gyermeknevelés Tudományos Folyóirat, (9)1,300-319. https://doi.org/10.31074/gyntf.2021.1.300.319

Gönczöl, A. (2021). Olvasóvá nevelés óvodáskorban a drámapedagógia módszereivel - A mese komplex személyiségfejlesztő hatása. Gyermeknevelés Tudományos Folyóirat, (9)1, 250-260. https://doi.org/10.31074/gyntf.2021.1.250.260

Kerekes, G. (2021). Ungarndeutsche Kinderliteratur: Josef Michaelis` Zauberhut. Gyermeknevelés Tudományos Folyóirat, (9)1, 145-161. https://doi.org/10.31074/ gyntf.2021.1.145.161

Lengyelné Molnár, T., Racsko, R. \& Szűts, Z. (2021). A kommunikációs kompetencia fejlesztésének új lehetőségei: digitális történetmesélés LEGO $^{\circ}$ eszközzel. Gyermeknevelés Tudományos Folyóirat, (9)1, 327-339. https://doi.org/10.31074/ gyntf.2021.1.327.339

Lózsi, T (2021). Hisztiretorika. Gyermeknevelés Tudományos Folyóirat, (9)1, 115130. https://doi.org/10.31074/gyntf.2021.1.115.130

Márkus É. (2021). Baranya megyei német népmesék a nemzetiségi oktatásban - Az Ördögcsúcs címủ mesekötet. Gyermeknevelés Tudományos Folyóirat, (9)1, 131144. https://doi.org/10.31074/gyntf.2021.1.131.144

Mukics, J. (2021). Neil Gaiman Coraline címü regényének komparatisztikai vizsgálata. A gyermeki lélek vágyai fantázia és valóság határán. Gyermeknevelés Tudományos Folyóirat, (9)1, 162-190. https://doi.org/10.31074/gyntf.2021.1.162.190

Nagy, N. (2021). Tulajdonnevek kárpátaljai népmesékben a Három arany nyílvessző című népmesegyűjtemény alapján. Gyermeknevelés Tudományos Folyóirat, (9)1, 162-190. https://doi.org/10.31074/gyntf.2021.1.162.190

Pölcz, Á. (2021). Hallgatólagos tudás az anyanyelvi nevelésben. A gyermekirodalom szerepe a nyelvi tudatosság kialakításában. Gyermeknevelés Tudományos Folyóirat, (9)1, 218-229. https://doi.org/10.31074/gyntf.2021.1.218.229 